\title{
Front Matter: Volume 9687
}

, "Front Matter: Volume 9687," Proc. SPIE 9687, 8th International Symposium on Advanced Optical Manufacturing and Testing Technologies: Subnanometer Accuracy Measurement for Synchrotron Optics and X-Ray Optics, 968701 (9 November 2016); doi: 10.1117/12.2257119 and Testing Technology (AOMATT2016), 2016, Suzhou, China 


\title{
PROCEEDINGS OF SPIE
}

\section{8th International Symposium on Advanced Optical Manufacturing and Testing Technologies}

\section{Subnanometer Accuracy Measurement for Synchrotron Optics and X-Ray Optics}

\author{
Shinan Qian \\ Mourad Idir \\ Daniele Cocco \\ Tiqiao Xiao \\ Kazuto Yamauchi \\ Editors
}

\section{6-29 April 2016 \\ Suzhou, China}

Sponsored by

COS-The Chinese Optical Society

IOE-Institute of Optics and Electronics, Chinese Academy of Sciences

Technical Co-sponsor and Publisher

SPIE

Supporting Organizations

Ministry of Science and Technology of China (China)

Chinese Academy of Sciences (China)

National Natural Science Foundation of China (China)

Volume 9687 
The papers in this volume were part of the technical conference cited on the cover and title page. Papers were selected and subject to review by the editors and conference program committee. Some conference presentations may not be available for publication. Additional papers and presentation recordings may be available online in the SPIE Digital Library at SPIEDigitallibrary.org.

The papers reflect the work and thoughts of the authors and are published herein as submitted. The publisher is not responsible for the validity of the information or for any outcomes resulting from reliance thereon.

Please use the following format to cite material from these proceedings:

Author(s), "Title of Paper," in 8th International Symposium on Advanced Optical Manufacturing and Testing Technologies: Subnanometer Accuracy Measurement for Synchrotron Optics and X-Ray Optics, edited by Shinan Qian, Mourad Idir, Daniele Cocco, Tiqiao Xiao, Kazuto Yamauchi, Proceedings of SPIE Vol. 9687 (SPIE, Bellingham, WA, 2016) Article CID Number.

ISSN: 0277-786X

ISSN: 1996-756X (electronic)

ISBN: 9781628419221

Published by

SPIE

P.O. Box 10, Bellingham, Washington 98227-0010 USA

Telephone +1 3606763290 (Pacific Time) · Fax +1 3606471445

SPIE.org

Copyright (C) 2016, Society of Photo-Optical Instrumentation Engineers.

Copying of material in this book for internal or personal use, or for the internal or personal use of specific clients, beyond the fair use provisions granted by the U.S. Copyright Law is authorized by SPIE subject to payment of copying fees. The Transactional Reporting Service base fee for this volume is $\$ 18.00$ per article (or portion thereof), which should be paid directly to the Copyright Clearance Center (CCC), 222 Rosewood Drive, Danvers, MA 01923. Payment may also be made electronically through CCC Online at copyright.com. Other copying for republication, resale, advertising or promotion, or any form of systematic or multiple reproduction of any material in this book is prohibited except with permission in writing from the publisher. The CCC fee code is $0277-786 \mathrm{X} / 16 / \$ 18.00$.

Printed in the United States of America.

Publication of record for individual papers is online in the SPIE Digital Library.

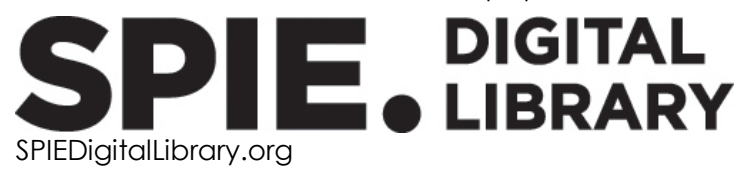

Paper Numbering: Proceedings of SPIE follow an e-First publication model. A unique citation identifier (CID) number is assigned to each article at the time of publication. Utilization of CIDs allows articles to be fully citable as soon as they are published online, and connects the same identifier to all online and print versions of the publication. SPIE uses a six-digit CID article numbering system structured as follows:

- The first four digits correspond to the SPIE volume number.

- The last two digits indicate publication order within the volume using a Base 36 numbering system employing both numerals and letters. These two-number sets start with $00,01,02,03,04,05$, $06,07,08,09,0 A, 0 B \ldots$. OZ, followed by 10-1Z, 20-2Z, etc. The CID Number appears on each page of the manuscript. 


\title{
Contents
}

\author{
$\checkmark \quad$ Authors \\ vii Symposium Committees \\ ix Introduction \\ xi Sponsors
}

ORAL SESSION

968702 Comparison of small angle deflectometric measurements with different apertures down to the sub-millimetre range (Invited Paper) [9687-8]

968703 How to specify super-smooth mirrors: simulation studies on nano-focusing and wavefront preserving x-ray mirrors for next-generation light sources [9687-2]

$968704 \quad$ New scheme to control x-ray deformable mirrors [9687-3]

968705 Evaluation of figure accuracy of Wolter mirror fabricated by electroforming [9687-7]

968706 Two dimensional surface slope metrology with enhanced spatial resolution based on wavefront coding method [9687-9]

968707 High accuracy measurement of power spectral density in middle spatial frequency range of optical surfaces using optical profiler [9687-6]

$968708 \lambda / 100$ reference flat for commercially available Fizeau interferometer [9687-5]

9687 OA Control of lateral thickness gradients of EUV/soft x-ray multilayer on curved substrates [9687-11]

\section{POSTER SESSION}

9687 OB An analysis of light spot extracting based on LED [9687-4]

9687 OC Research on the electron beam spot detection methods based on SEM [9687-10]

9687 OD Innovative nano-accuracy surface profiler for sub-50 nrad rms mirror test [9687-12]

9687 OE Nano-accuracy measurement technology of optical-surface profiles [9687-13]

9687 OF Progress in upgrading a long trace profiler at NSRRC [9687-14]

9687 OG X-ray optics R\&D at NSLSII: focus on optical metrology development [9687-15] 
Proc. of SPIE Vol. $9687968701-4$

Downloaded From: https://www.spiedigitallibrary.org/conference-proceedings-of-spie on 25 Apr 2023 Terms of Use: https://www.spiedigitallibrary.org/terms-of-use 


\section{Authors}

Numbers in the index correspond to the last two digits of the six-digit citation identifier (CID) article numbering system used in Proceedings of SPIE. The first four digits reflect the volume number. Base 36 numbering is employed for the last two digits and indicates the order of articles within the volume. Numbers start with 00, 01, 02, 03, 04, 05, 06, 07, 08, 09, OA, OB...0Z, followed by 10-12, 20-2Z, etc.

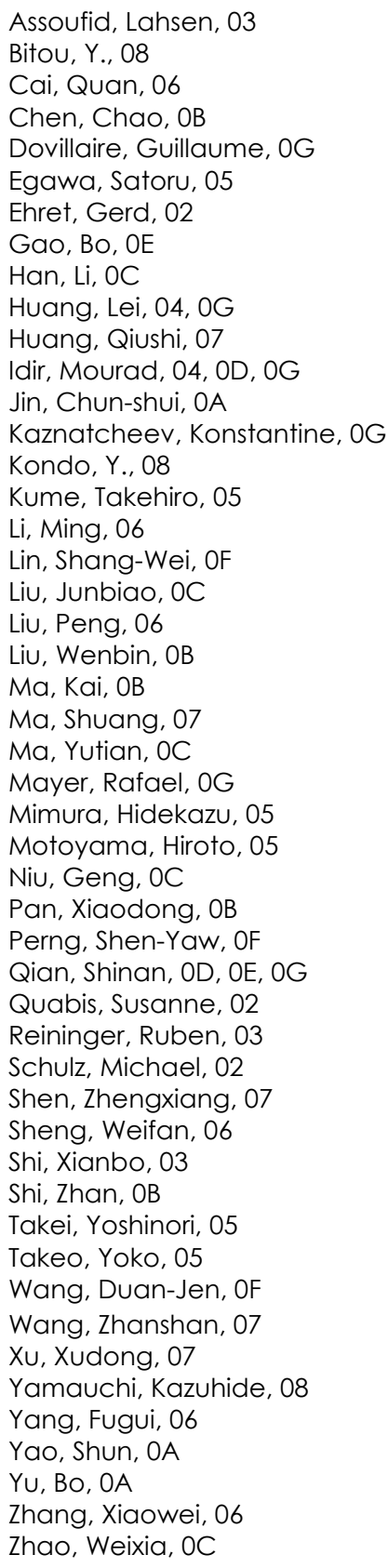


Proc. of SPIE Vol. $9687968701-6$

Downloaded From: https://www.spiedigitallibrary.org/conference-proceedings-of-spie on 25 Apr 2023 Terms of Use: https://www.spiedigitallibrary.org/terms-of-use 


\section{Symposium Committees}

Honorary Chair

Guangcan Guo, The Chinese Optical Society (China) and Chinese Academy of Sciences (China)

Symposium General Chair

Liwei Zhou, Beijing Optical Society (China) and Beijing Institute of Technology (China)

Symposium General Co-chairs

Jianlin Cao, Ministry of Science and Technology of China (China)

David R. Silva, National Optical Astronomy Observatory (United States)

Eric Mazur, Harvard University (United States)

H. Philip Stahl, NASA Marshall Space Flight Center (United States)

Yinnan Yuan, Soochow University (China)

Yudong Zhang, Chengdu Branch, Chinese Academy of Sciences (China)

International Advisory Committee

Wenhan Jiang, Institute of Optics and Electronics (China)

Junhua Pan, Soochow University (China)

Marc Cayrel, European Southern Observatory (Germany)

Liangchi Zhang, The University of New South Wales (Australia)

Ralf D. Geckeler, Physikalisch-Technische Bundesanstalt (Germany)

Oltmann Riemer, Universität Bremen (Germany)

Organizing Committee

Enhai Liu, Chair, Institute of Optics and Electronics, CAS (China)

Jinghua Cao, Co-chair, Chinese Academy of Sciences Bureau of International Cooperation (China)

Libin Xiang, Co-chair, Shanghai Engineering Center for Microsatellites (China)

Yadong Jiang, Co-chair, University of Electronic Science and Technology of China (China)

Chinhua Wang, Co-chair, Soochow University (China)

Shinan Qian, Brookhaven National Laboratory (United States)

Myung K. Cho, National Optical Astronomy Observatory (United States) 


\section{Program Committee}

Xiangang Luo, Chair, Institute of Optics and Electronics, CAS (China)

Yuwen Qin, Co-chair, National Natural Science Foundation of China (China)

Jingchi Yu, Co-chair, Soochow University (China)

Symposium General Secretary

Li Yang, Committee of Optical Manufacturing Technology COS (China) 


\section{Introduction}

The 8th International Symposium on Advanced Optical Manufacturing and Testing Technology (AOMATT 2016) was held 26-29 April 2016 at the Suzhou International Conference Center, Suzhou, China. The symposium was opened in the morning of 26th April with a formal opening ceremony. The ceremony started with the introduction of VIP guests, symposium chairs, conference chairs, and plenary speakers. Professor Liwei Zhou AOMATT 2016 Symposium Chairman, Professor Bin XU Vice President of Institute of Optics and Electronics (China), one of the sponsors of AOMATT 2016, and Professor Yuan Yinnan, Vice President of Soochow University (China) gave opening speeches to a packed auditorium.

Plenary sessions followed immediately after the conclusion of the opening ceremony. There were a total of eight plenary presentations: "Less is more: extreme optics with zero refractive index physics", by Dr. Eric Mazur, Balkanski Professor of Physics and Dean of Applied Physics at Harvard University (United States); "Large optical telescopes in the era of large wide-field survey", by Dr. David R. Silva, Director of United States National Optical Astronomy Observatory (United States); "The European Extremely Large Telescope (E-ELT) revolution is under construction", by Dr. Marc Cayrel, European Southern Observatory (ESO) Project Manager, E-ELT Optomechanics (Germany); "Ultra-precision lens fabrication via molding: advances and challenges", by Dr. Liangchi Zhang, Professorial Fellow of Australian, Head of the Laboratory for Precision and Nano Processing Technologies, The University of New South Wales (Australia); "Advancing ultra-precision machining to high performance", by Dr. Ing. Oltmann Riemer, Head of the Laboratory for Precision Machining, Universität of Bremen (Germany); "Micro/nano-optics for flexible functional devices: today and future", by Dr. Linsen Chen, Chief of National United Engineering Research Center of Digital Optical Imaging and Display, Soochow University (China); "New angles on angle metrology: approaching fundamental limits", by Dr. Ralf D. Geckeler, Head of Length and Angle

Graduations Group, Physikalisch-Technische Bundesanstalt (Germany); and "Functional photonic nanostructures: from thin films and slits to catenaries", by Dr. Xiangang Luo, Director of State Key Laboratory of Optical Technologies for NanoFabrication and Micro-Engineering, Chinese Academy of Sciences (China).

More than 800 people attended the opening ceremony and full-day plenary sessions. More than 1,000 abstracts were submitted to AOMATT 2016. About 500 submissions were selected for oral and poster presentations after careful reviews by conference chairs and committee members. Oral papers were presented in eight parallel conference sessions 27 and 28 April. An all-symposium poster session was held in the afternoon of 28 April. Many papers highlighted cutting edge research and development in optical design, manufacturing, and testing. Authors and attendees had very productive discussions and exchanged ideas throughout the symposium. 
The AOMATT 2016 organizing committee would like to express their sincere appreciation for the strong support of SPIE, technical co-sponsor and long-term partner of AOMATT. Dr. Andrew Brown, Senior Director of SPIE, sent a letter of congratulations to the symposium. In his letter, Dr. Brown thanked all symposium chairs, conference chairs, and committee members for their leadership, and all authors and attendee for their contributions to make AOMATT 2016 a success. Dr. Brown also stated: "The vision of AOMATT is closely aligned with SPIE's mission to promote optics and photonics around the world. SPIE sponsors and co-sponsors technical conferences around the world and contribute millions of dollars every year in support of education and outreach programs, such as scholarships, travel grants, and other educational programs."

Finally, we would like to express our sincere appreciation to COS-The Chinese Optical Society (China), and IOE-Institute of Optics and Electronics, Chinese Academy of Sciences (China), for sponsoring and supporting AOMATT 2016. We want to thank all authors and participants as well volunteers for their contributions to the symposium and sharing their research with colleagues around the world.

We look forward to seeing everyone at AOMATT 2018.

Li Yang

Secretary General, AOMATT 2016

Committee of Optical Manufacturing Technology (COMT), COS 


\section{Sponsors}

Sponsored by

COS-The Chinese Optical Society (China)

IOE-Institute of Optics and Electronics, Chinese Academy of Sciences (China)

Technical Co-sponsor

SPIE

Local Supporting Organization

Soochow University (China)

Supporting Organizations

Ministry of Science and Technology of China (China)

Chinese Academy of Sciences (China)

National Natural Science Foundation of China (China)

Cooperating Organizations

National University of Defense Technology (China)

University of Electronic Science and Technology of China (China)

Sichuan University (China)

State Key Laboratory of Optical Technologies for Nano-Fabrication and Micro-Engineering (China)

Key Laboratory of Adaptive Optics, Chinese Academy of Sciences (China)

Changchun Institute of Optics, Fine Mechanics and Physics (China)

University of Shanghai for Science and Technology (China)

Beijing Institute of Technology (China)

Changchun University of Science and Technology (China)

Nanjing University of Science and Technology (China)

The Hong Kong Polytechnic University (Hong Kong, China)

Zhejiang Quartz Crystal Optoelectronic Technology Company, Ltd. (China)

Suzhou Association for Sciences and Technology (China)

Optical Society of Sichuan Province (China)

Managed by

COS-The Chinese Optical Society (China) 
Proc. of SPIE Vol. $9687968701-12$

Downloaded From: https://www.spiedigitallibrary.org/conference-proceedings-of-spie on 25 Apr 2023 Terms of Use: https://www.spiedigitallibrary.org/terms-of-use 